\title{
TOTAL SUSPENDED SOLID DISTRIBUTION IN HAU RIVER USING SENTINEL 2A SATELLITE IMAGERY
}

\author{
T. H. D. Nguyen ${ }^{1 *}$, K. D. $\operatorname{Phan}^{1}$, H. T. T. Nguyen ${ }^{2}$, S. N. Tran ${ }^{1}$, T. G. $\operatorname{Tran}^{1}$, B. L. Tran ${ }^{1}$, T. N. Doan ${ }^{1}$ \\ ${ }^{1}$ College of Environment and Natural Resources, Can Tho University, Vietnam \\ (nthdiep, pkdiem, tsnam, tblinh)@ctu.edu.vn, (giamb1602021,nhiB1606276)@student.ctu.edu.vn \\ 2 Tay Nguyen University, Vietnam \\ huongthanh.frem@gmail.com
}

\section{Commission IV}

KEY WORDS: Setinel 2A satellite imagery, Normalized Suspended Material Index (NSMI), total suspended solids (TSS), An Giang province.

\begin{abstract}
:
This research was applied high-resolution Sentinel-2A imagery which aims to monitor a suitability of MultiSpectral Imager (MSI) at higher resolution $(10 \mathrm{~m})$ for mapping of Total Suspended Solids (TSS) ) in the upper reaches of the Mekong Delta - An Giang province. The field survey is carried out to collect TSS at random distribution sites outside full-dyke protection. A remote sensing algorithm with a regression function method is developed to estimate TSS concentration automatically to select between the most sensitive TSS and water reflectance relationship. The regression analytical algorithm is predicted the output values based on normalized suspended material index (NSMI) $\left(r^{2}=0.92\right)$, showing the MSI sensor's great potential to estimate TSS. The results confirm that suspended materials in the surface water reached the minimum of $10.36 \mathrm{mg} / \mathrm{l}$ and the maximum of $328.56 \mathrm{mg} / \mathrm{l}$ in An Giang province, the suspended materials distributional tendency with high content was mainly in flooded fields near the upstream of the basin of Hau river, especially in areas without the dike enclosure and the content was low in the areas within the dike enclosure. These findings promote further research in water quality studies relying on both operational Sentinel-2A and Sentinel-2B imageries with great implications to improve the understanding of turbid coastal and inland water environments.
\end{abstract}

\section{INTRODUCTION}

Suspended sediment is an important factor in determining the quality of water (Xue Z, 2011) such as water clarity, reservoir storage and sediment serves as a vehicle for the transport of many binding contaminates, including nutrients, trace metals, semi-volatile organic compounds, and numerous pesticides (EPA, 2000). The monitoring of suspended sediment components is critical to implement the effect of the environmental management (Duan W., 2013). However, the spatial and temporal heterogeneity of water bodied layers combined the conventional sampling methods leading to an inadequate monitoring and characterization of water quality (Liu Y., 2003). Thus, the application of remote sensing to assess inland water quality has been recognized recently because its capability of scanning wide water bodies within a short time period (2003). Consequently, a combined approach of the spatial and temporal remote sensing with conventional water sampling presents a potentially effective solution to monitor freshwater environment (Yang W., 2011).

In relation to water quality, sediments transport and erosion that is complex natural process has strongly affected by human activities such as deforestation, agriculture and urbanization. In particular, suspended sediment plays a key role in controlling water quality that can cause of a major reduction on stream capacity for handling flood waves (Arnold JG., 1995). Sediment is the most common component both in weight and volume in surface waters of fresh water systems. Thus, the effect of the other optical active substances especially for turbid rivers on the satellite data is negligible (Lal R (1994). Over the past three decades, remotely sensed images have been widely applied in the suspended sediment assessment (Olsen DM., 2002; Dudgeon D., 2005). Relative to large water bodies, such as lakes and reservoirs, water in rivers are more immediately sensitive to and more directly influenced by the characteristic of the river bank, human activities, and other external forces (Palmer MA., 2009). Therefore, the successful application of remote sensing technology to suspended sediment load monitoring of rivers could be a very useful tool for management and development at basin scales (Julian JP., 2008).

The Mekong River is Asia's third largest trans-boundary river basin that covers an area of 795,000 $\mathrm{km}^{2}$, and discharge of $475 \mathrm{~km}^{3}$ an annual (MRC, 2005). Each year, the Mekong delivers approximately 160 million tons of sediment to the East Sea (Milliman, J et al., 1992). Sediment supplying changes in the Mekong River most likely caused by dam retention and channel-bed sand extraction in the Mekong delta that are suspected to the cause of erosion patterns observed in the Mekong delta (Anthony, E.J et al., 2015). However, it is difficult to detect the changes of sediment transport to discharge on the Lower Mekong River because of the limitation on field data, despite the fact that the Lower Mekong Basin is facing a similar pressures of population growth, land use change, infrastructure development, and reservoir construction that is simultaneously reducing the total sediment flux to coastal environments (Syvitski, J.P.M et al., 2005).

Sediment transport by rivers impacts on channel morphology, aquatic ecosystems, reservoir storage capacity, and ultimately the growth or retreat of delta environments (Anthony, E.J et al., 2015), it is a neccesary to detect the changes of sediment concentration and transport to effective basin management. Timely information on total suspended matter is critical for land managers to assess the effects of a wide range of issues caused by poor water quality. However, collection of reliable suspended sediment concentration data at the spatial and temporal imagery resolution necessary for effective basin 
management and planning can often be prohibitively time consuming and expensive in large rivers.

Remote sensing technique can be an efficient tool for mapping terrigeneous substances in surface water, and hence provide information to help managers in monitoring and controlling water quality. Many studies show that the reflectance of water which was determined from optical remote sensed data is strongly correlated with the concentration of water quality parameters (Frohn and Autrey 2007; Gilerson et al. 2010; Ritche et al. 1974), including suspended sediment (Mobley 1994; Ritchie and Cooper 1988; He et al. 2008; Nguyen et al. 2016; Markert et al. 2018). Therefore, optical satellite imagery has been used effectively for the assessment and monitoring of suspended sediment concentration.

The relationship between Landsat data and suspended sediment concentration has been proven by many researchers (Chalov et al. 2017; Olet 2010; Ritchie et al. 1990; Wang et al. 2009; Zhou et al. 2006; Trinh and Tarasov 2016; Wakerman et al. 2017; Yepez et al. 2018). In the study (Doxaran et al. 2006), the authors used the ratio of the nearinfrared and green bands of Landsat ETM+ multispectral images to determine concentration of suspended sediment and turbidity in the Gironde estuary (southest France). In the study (Trinh and Tarasov 2016), the authors used Landsat 7 ETM+ data and 10 ground truth sampling stations for calculating suspended sediment concentration in Tri An reservoir, Vietnam. Li et al. describe an empirical algorithm using MODIS data to identify areas with suspended sediments in turbid waters and shallow waters with bottom reflections ( $\mathrm{Li}$ et al. 2003). MODIS data also used in study (Guzman and Santaella 2009) to calculate concentration of suspended sediment in Mayaguez Bay (Puerto Rico). Chen et al. have used EO-ALI satellite imagery and found negative regression model between water turbidity in the Pearl River Estuary and reflectance at $570 \mathrm{~nm}$ (Chen et al. 2009).

Nowadays, many satellites with high enought spatial resolution have been used in water quality monitoring studies. For instance, Nguyen et al. found that the ratio of band 5 and band 4 using Sentinel 2A multispectral image yielded a good estimation of chlorophyll-a and suspended sediment in West Lake, Hanoi, Vietnam (Nguyen et al. 2016). Doxaran et al. (2002), Gernez et al. (2015) investigated the relationship between suspended sediment concentration and spectral paramerters of SPOT 4 and SPOT 5 sensors data. Sentinel 2 MSI data was used in study (Liu et al. 2017) to retrieve suspended particulate matter concentrations in Poyang lake (China). Because each river has a unique spectral characteristics, models for calculating suspended sediment concentration must be created for each of them. This study focused on established and analyzed Sentinel-2A multispectral imagery to retrieve suspended sediment concentration in the Hau River, Vietnam.

\section{STUDY AREA AND DATA}

\subsection{Study Area}

The Vietnamese Mekong Delta stretches from Tan Chau and Chau Doc stations to My Thuan and Can Tho stations at the Tien River and Hau River, respectively, with an area of about $19500 \mathrm{~km} 2$. The VMD is known as the most complex river delta in the world as a result of the immense anthropogenic interference encompassing numerous man-made channels, dikes, sluices gates and pumps (Manh et al. 2014).. In the
Vietnam Mekong Delta (VMD), sediment deposition is especially regnized to provide Potassium (K), a staple fertiliser in rice agriculture (Hoa et al. 2006). According to Manh et al. (2014), suspended sediment was estimated by the annual deposition of sediment-bound nutrients to supply over half of the fertilisation $(\mathrm{N}, \mathrm{P}, \mathrm{K})$ needed for supplyoing rice agriculture. In previous time, low dyke, double-cropping system, these nutrients were typically deposited during the 2 3 months of fluvial inundation brought by the summer monsoon. Hau River or Bassac River is the biggest branch of Mekong River in the lower basin. With a length of $226 \mathrm{~km}$, Hau River flows through different areas of the MD including An Giang (104 km), Can Tho (48km), Hau Giang (15km) and Soc Trang $(59 \mathrm{~km})$ carrying suspended sediment resources which contribute significantly sediment to the coastal region.

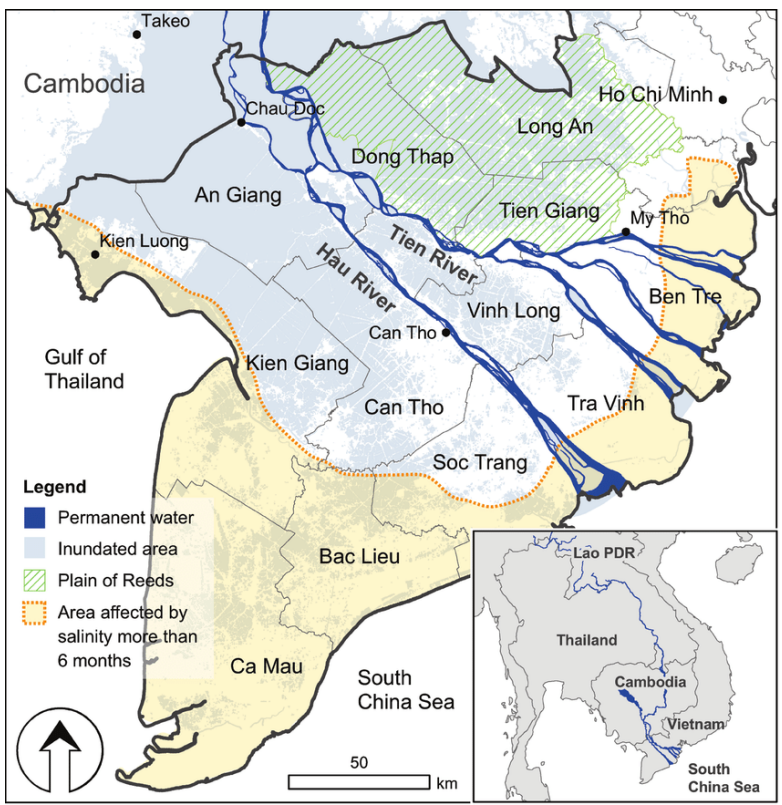

Figure 1. Situation downstream of Mekong River - Mekong Delta in Viet Nam maps

\subsection{Data used}

The satellite data used in this study is Sentinel-2A image that covers the study area in July 30, 2019 and August 19, 2019 and it has $<10 \%$ of cloud cover. Sentinel-2A scenes were downloaded from the Sentinel's Scientific Data Hub (https://scihub. copernicus.eu/). These images corresponded to Level-1C (L1C) products at Top Of Atmosphere (TOA) that systematically acquires optical imagery at high spatial resolution $(10-60 \mathrm{~m})$ over land and coastal waters. Sentinel2A data product is managed by European Space Agency (ESA). It aims at monitoring variability in land surface conditions and its wide swath width $(290 \mathrm{~km})$. The revisit time in the area of study is 12 days.

\subsection{Field Measurement of Suspended Sediment Concentration}

Water samples were collected near the surface $(0.3-0.5 \mathrm{~m})$ using a bottle at the main river, main water entrances and water land field. These surface samples provide an excellent comparison with remotely sensed optical properties which are most representative of shallow depths. 
These samples were transported to laboratory analysis for SSC determination, by filtration using $0.45 \mu \mathrm{m}$ paper filters, filtering the samples until filter saturation. The protocol of analysis followed the methodology Standard Methods (APHA, 1998). The 32 water samples were randomly selected from 42 total samples for modeling and the remaining 10 samples for verification. These water samples are used for regression analysis due to sampling at the same time with satellite image acquisition (Fig. 2).

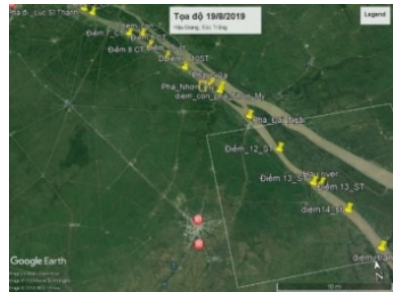

(a)

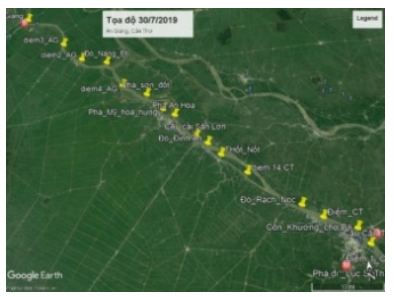

(b)
Fig. 2. Sampling locations in study area - Hau River (a) July 30, 2019 and (b) August 19, 2019.

\section{METHODOLOGY}

\subsection{Sentinel 2 MSI Atmospheric Correction}

Sentinel 2 MSI L1C products provide the top of atmosphere reflectance $\left(\rho_{T O A}\right)$, which is assumed to be the sum of Rayleigh reflectance $\left(\rho_{r}\right)$, reflectance $\left(\rho_{a}\right)$ and water(a) aerosol reflectance $\left(\rho_{w}\right)$ :

$$
\rho_{\mathrm{TOA}}=\rho_{\mathrm{r}}+\rho_{\mathrm{a}}+\mathrm{t}^{*} \rho_{\mathrm{w}}
$$

Where $t$ is the two-way diffuse atmospheric transmittance (Gordon, H.R et al., 1994).

The reflectance caused by Rayleigh scattering was estimated with the $6 \mathrm{~S}$ radiative transfer code for each band, meanwhile the diffuse atmospheric transmittance $(t)$ was also derived (Vermote, E.F et al., 1997). A mid-latitude atmosphere condition was adopted and the mean values of solar and view zenith and azimuth across the whole granule were calculated for the sun and sensor geometry (Vanhellemont, Q et al., 2015 and Wang, M., 2006).

\subsection{Normalized Suspended Material Index (NSMI)}

The algorithm used to obtain the value model is an TSS transformation using Normalized Suspended Material Index algorithm (NSMI). NSMI is one of the universal transformations that is often used. The image transformation value for NSMI was calculated using (2). The closer to -1 indicates that the water is clearer.

$$
\mathrm{NSMI}=\frac{\rho \mathrm{RED}+\rho \mathrm{GREEN}-\rho \text { BLUE }}{\rho \mathrm{RED}+\rho \mathrm{GREEN}+\rho \text { BLUE }}
$$

The result of spectral transformation based on index is done by linear and non-linear regression analysis with field measurement value. The highest regression value is used as the most appropriate index.

\subsection{Statistical Methods}

The selected image index was applied to analyze an empirical model of SSC from the calibration dataset. Four statistical models were optimized between the image index and SSC measurements include: (1) linear; (2) exponential; (3) 2nd order polynomial; and (4) logarithm functions. Each model was tested on the selected image index using the following objective functions: coefficient of determination $\left(\mathrm{R}^{2}\right)$, sum of square error (SSE), and significance (p). The resulting model fit statistics were used to rank the best performing model based on the calibration dataset that was applied on the validation dataset and statistically analyzed to understand the accuracy and errors associated with estimating SSC using the specified approach.

\subsection{Validation dataset}

The correlation analysis between NSMI values and SSC field data was implemented. The calibrated models were applied to estimate the SSC values of validation dataset. The coefficient of determination $\left(\mathrm{R}^{2}\right)$, Bias, and root mean square error (RMSE) between the measured data and estimated values were calculated to assess the fitting and validation accuracy. Four models with better fitting and validation accuracies were selected for further analysis.

\section{RESULTS AND DISCUSSIONS}

\subsection{Normalized Suspended Material Index (NSMI)}

The Normalized Suspended Material Index (NSMI) is estimated and normalized based on the spectral reflectance in the channels in the visible wave range including the blue, green and red channels on the image. The results of NSMI values range from -0.03 to +0.94 (the first time sampling) (Fig. 3a) and from -0.09 to 0.78 (the second time sampling) (Fig. 3b). Low values correspond to clear water (negative values of the indices indicate presence of clear water). Higher values correspond to turbid water with a lot of suspended solids (SS) (Fig. 3).



(a)

(b)

Fig. 3. Normalized Suspended Material Index Image (NSMI) (a) July 30, 2019 and (b) August 19, 2019

\subsection{Regression models}

Based on the result of regression test, it is developed by the regression corelation between NSMI image and SSC on the field survey. Visible light has slightly more energy than invisible infrared radiation and is more readily absorbed by water than other visible wavelengths. Light with longer wavelengths is absorbed more quickly than that with shorter wavelengths. The equation uses to understand the suspended solid content in water to show on equation (3) and (4) as follows: 


$$
\begin{aligned}
& \operatorname{TSS}(30 / 7 / 2019)=412.97 \mathrm{x}^{2}-177.19 \mathrm{x}+24.18 \\
& \operatorname{TSS}(19 / 8 / 2019)=1309 \mathrm{x}^{2}-778.4 \mathrm{x}+150.81
\end{aligned}
$$

It is ascertained that the quadratic polynomial regression has the highest coefficient of determination $\mathrm{R}^{2}=0.92$ and 0.83 (Figure $4 \mathrm{a}, 4 \mathrm{~b}$ ). This regression equation is used to predict the values of the TSS variables (dependent variables) based on the values of the NSMI variables (independent variables). Based on the model, it is shown that the NSMI variable reflects $92.66 \%$ and 83,39 of the variation of the TSS variables in the 2 nd order polynomial regression equation.

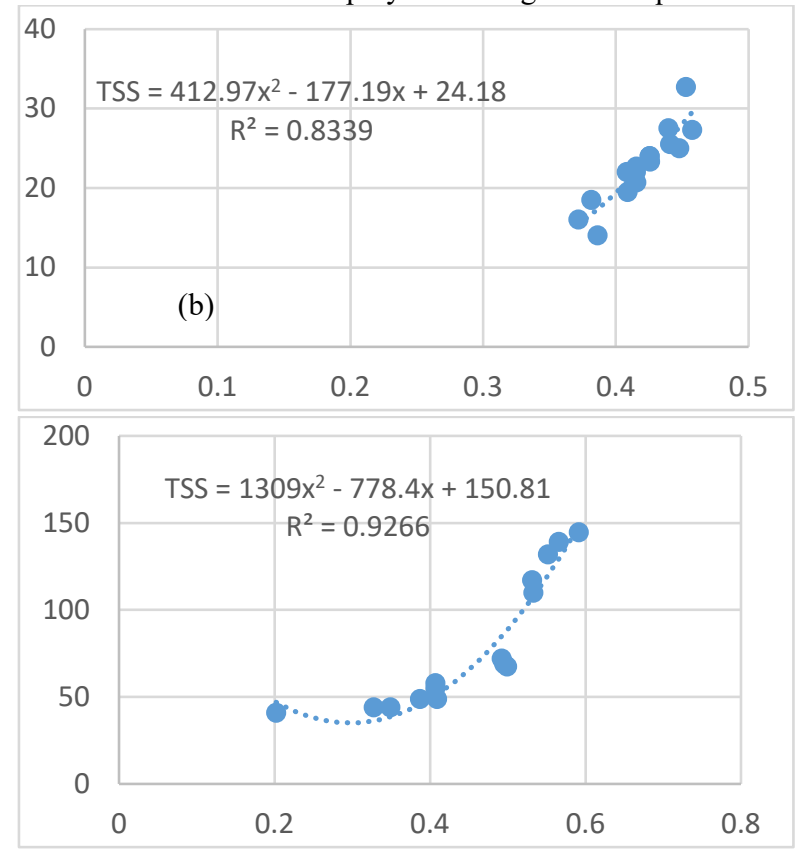

Fig. 4: 2019 Suspended Solid Concentration (SSC) retrieval models based on NSMI

\subsection{Determining suspended solid concentration (SSC)}

The distribution of SSC in the surface water in An Giang province, Mekong Delta is shown in Figure 5. The lowest value of the suspended solids content in surface water for the first sampling and the second sampling in An Giang province are $5,17 \mathrm{mg} / \mathrm{l}$ and $35,09 \mathrm{mg} / 1$ while the highest value reaches $171.24 \mathrm{mg} / \mathrm{l}$ and $343,73 \mathrm{mg} / \mathrm{l}$, respectivelly. The concentration of suspended matter in surface water is highest in the downstream of Hau River.

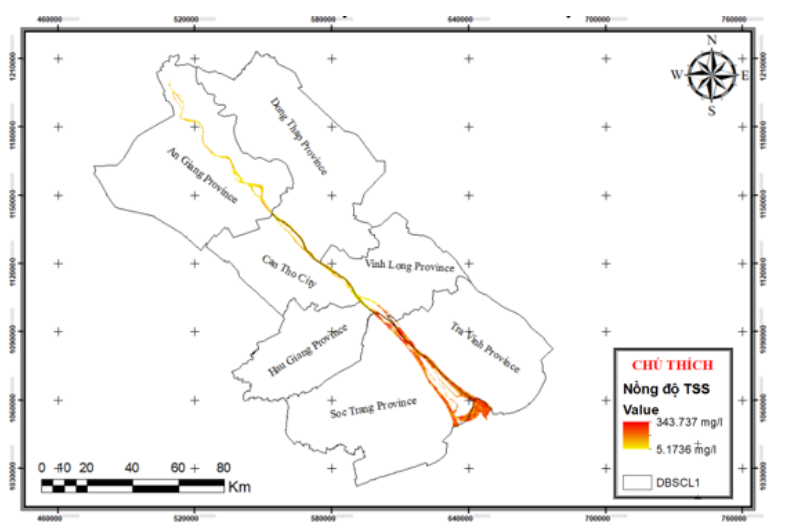

Figure 5: The suspended solid concentration distribution on surface water in An Giang province

The SSC concentrates mainly on the Hau River bank and flood areas outside the dike zone. Due to heavy rains, materials are washed away from both sides of the river and follow the flow from upstream to the river basin and into the flooded fields. SSC exceeds the permitted threshold of 100 mg/l according to QCVN 08-MT: 2015/BTNMT, mostly distribuited in Tan Chau district, in flood parts of Chau Thanh district, An Phu and along Hau river bank. Meanwhile, the surface water quality in the dike zone area and at the end of the branches of Hau river has the TSS content within the permitted threshold (10.36 -100 mg/l) (Figure 6).



Figure 6: SSC distribution on the surface water exceeding 100 $\mathrm{mg} / \mathrm{l}$ (TCVN, 2015) in An Giang province

\subsection{Reliability assessment}

The study uses data collected at 10 water quality sampling points and analyzes the TSS content. The suitability of the model depends on correlation coefficient (r), coefficient of determination $\left(\mathrm{R}^{2}\right)$ and deviation of the model (Bias and RMSE). The results of the regression model assessment in Figure 7 show the correlation between SSC measurement and SSC imagery. The regression model has significant statistics due to four paremeters consists of correlation coefficient (r), coefficient of determination $\left(\mathrm{R}^{2}\right)$, deviation (Bias) and root mean square error (RMSE) with the value of $0.97 ; 0.96 ; 0.2$ $\mathrm{cm}$ and $6.21 \mathrm{~cm}$, respectively.

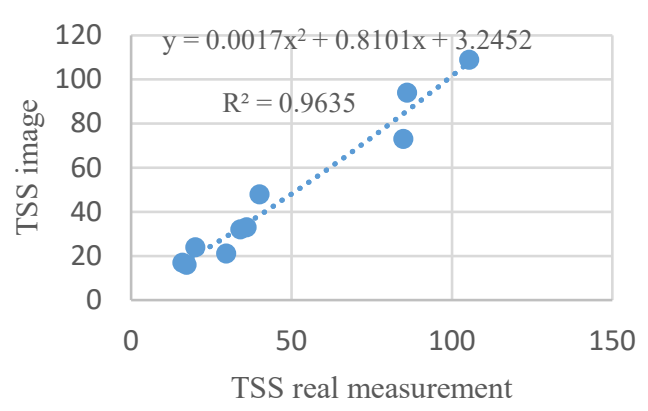

Figure 7: Correlation results between the measured TSS content and the imagery TSS (Quadratic polynomial)

In this study, 10 water samples were used to evaluate the accuracy of the regression model. Comparison between concentration of suspended sediment at the measurement points and the results calculated from NSMI image for the 
first sampling from $0.7 \mathrm{mg} / 1$ to $3.7 \mathrm{mg} / \mathrm{l}$ and the secong sampling from $2.2 \mathrm{mg} / 1$ to $13 \mathrm{mg} / \mathrm{l}$. It shows the difference between concentration of suspended sediment calculated from remote sensing imagery and ground truth data range of two sampling times.

\section{DISCUSSIONS}

Hau River is a main river branch of the lower of Mekong River that has high concentration of suspended sediment, especially in the bank of the downstream of Hau river. This can be explained by flowing sediment into the estuaries. The obtained results in this study indicate that water in Hau River is suitable for irrigation purposes or similar water quality purposes with low quality water requirements.

The Sentinel 2A remote sensing imagery and derivation of horizontal variations in TSS has provided a sound basis for comparisons with output from models between NSMI and TSS concentration. The combination of remote sensing and modelling can provide a powerful tool to improve predictions of TSS in Hau River and contribute to greater confidence in modelling of various management scenarios.

There is high potential for the 2 nd order polynomial model to be adapted for estimation of the concentrations of additional water quality constituents, particularly those that are associated with suspended sediments. Future work on this system will concentrate on utilizing additional sensors, such as Sentinel-2A, to improve temporal resolution of satellite observations. Sentinel-2A has been shown to provide high quality estimates of suspended sediments and other water quality parameters (Toming, $\mathrm{K}$ et al., 2016).

The high temporal resolution has an advantage of is obvious, since frequent observations would enable TSS monitoring over short periods. Sentinel 2 MSI provides a revisit time of 5-day at the equator with the full operations of the two satellites (Drusch M., 2012). According to Novoa et al. (2017) was considering its capability in TSS retrieval demonstrated in the study, Sentinel 2 MSI should be an ideal data source for the operational TSS monitoring in Hau River to be developed a switching model for low-to-high turbidity waters, which used red band for low-to-medium turbid waters and NIR band for high turbid waters to retrieve CSPM values. Developing a switching model based on Sentinel 2 MSI and NSMI using this modeling strategy might work better to capture the complex spatiotemporal TSS patterns of the floodplain area. Moreover, further elaborate evaluation of the atmospheric correction and TSS retrieval accuracy with concurrent in-situ and satellite observations would be a meaningful task.

\section{CONCLUSION}

The study has determined the suspended solid concentration in the surface water of Hau River through the NSMI values applying the optical satellite imagery Sentinel 2A with total suspended solid (TSS) in surface water ranging around 10.36 - $328.56 \mathrm{mg} / \mathrm{l}$ based on the quadratic regression equation with the determination coefficient $\mathrm{R}^{2}=0.92$. The distribution of suspended solid concentration is significantly different between the headwater area of Hau river flowing to the end of the river branch and the area of An Phu, Tan Chau near the upstream of Hau river. This study is the prerequisite for monitoring the sediment content and analyzing the nutrient content in alluvium to support research on agricultural cultivation in the Mekong Delta.

\section{ACKNOWLEDGEMENT}

The authors thank the Department of Agriculture and Rural Development in An Giang province who has been very helpful in providing valuable materials and supporting us during the survey. We highly appreciate a valuable funded in part by the Technological Cooperation Project "Buiding capacity for Can Tho University to be an excellent institution of education, scientific research and techology transfer" of JICA. Our gratitude extends to the Can Tho University Improvemnent Project VN15-P6 which was funded by a Japanese ODA loan to all those who provided us the possibility to complete this research in ODA-E3 project. Lastly but of equal importance, we owes a great debt to project management board and the colleagues at College of Environment and Natureal Resources to support us during the period doing this project acomplishment. We thanks to European Space Agency for providing us with satellite data used in this study.

\section{REFERENCES}

Arnold JG, Williams JR, Maidment D R (1995) Continuous time water and sediment routing model for large basins. J Hydrol 121: 171-183.

Anthony, E.J.; Brunier, G.; Besset, M.; Goichot, M.; Dussouillez, P.; Nguyen, V.L. Linking rapid erosion of the Mekong River delta to human activities. Sci. Rep. 2015, 5, 14745

Chalov S., Golosov V., Tsyplenkov A., Zakerinejad R., Marker M., Samokhin M. (2017). A toolbox for sediment budget research in small catchments, Geography, Environment, Sustainability, 10(4), 43- 68, https://doi.org/10.24057/2071-9388-2017-10-4-43-68.

Chalov S., Bazilova V., Tarasov M. (2017). Modeling suspended sediment distribution in the Selenga River Delta using LandSat data, Proc. IAHS, 375, 19-22, doi:10.5194/ piahs-375-19-2017

Chen S., Fang L., Zhang L., Huang W. (2009). Remote sensing of turbidity in seawater intrusion reaches of Pearl River Estuary - A case study in Modaomen water way, China, Estuarine, Coastal and Shelf Science, 82(1), 119-127, https://doi.org/10.1016/j. ecss.2009.01.00.

Drusch, M.; Del Bello, U.; Carlier, S.; Colin, O.; Fernandez, V.; Gascon, F.; Hoersch, B.; Isola, C.; Laberinti, P.; Martimort, P. Sentinel-2: ESA's optical high-resolution mission for GMES operational services. Remote Sens. Environ. 2012, 120, 25-36

Doxaran D., Froidefond J.M., Lavender S., Castaing P. (2002). Spectral signature of highly turbid waters application with SPOT data to quantify suspended particulate matter concentrations, Remote Sensing of Enviroment, 81, 149 161

Doxaran D., Castaing P., Lavender S.J. (2006). Monitoring the maximum turbidity zone and detecting fine-scale turbidity features in the Gironde estuary using high spatial resolution satellite sensor (SPOT HRV, Landsat ETM+) data, International Journal of Remote Sensing, Vol. 27, No. 11, $2303-2321$ 
Duan W, Takara K, He B, Luo P, Nover D, et al. (2013) Spatial and temporal trends in estimates of nutrient and suspended sediment loads in the Ishikari River, Japan, 1985 to 2010. Sci Total Environ 461-462: 499-508.

Dudgeon D (2005) River rehabilitation for conservation of fish biodiversity in monsoonal Asia. Ecol. Soc. 10: 15.

Frohn R.C., Autrey B.C. (2007). Ohio River water quality assessment using Landsat 7 data, SWIMS Conference, Chicago, IL, January 30 - February 01 .

Gordon, H.R.; Wang, M. Retrieval of water-leaving radiance and aerosol optical thickness over the oceans with SeaWiFS: A preliminary algorithm. Appl. Opt. 1994, 33, 443-452.

Guzman V.R., Santaella F.G. (2009). Using MODIS 250m Imagery to Estimate Total suspended sediment in a Tropical open bay, International Journal of Systems Applications, Engineering \& Development, Vol. 3, Issue 1, 36 - 44.

He W., Chen S., Liu X., Chen J. (2008). Water quality monitoring in slightly - polluted body through remote sensing - a case study in Guanting Reservoir Beijing, China, Frontiers of Environmental Science \& Engineering, Vol. 1, $11 \mathrm{pp}$.

Ibáñez C, Canicio A, Day JW, Curco A (1997) Morphologic development, relative sea level rise and sustainablemanagement of water and sediment in the Ebro Delta, Spain. J Coast Conserv 3(2):191-202

Julian JP, Doyle MW, Powers SM, Stanley EH, Riggsbee JA (2008) Optical water quality in rivers. Water Resource Research 44.

Lal R (1994) Soil Erosion, Soil and Water Conservation Society. Ankeny, Iowa 340.

Liu Y, Islam MA, Gao J (2003) Quantification of shallow water quality parameters by means of remote sensing. Progress Physic Geog 27: 24-43.

Liu H., Li Q., Shi T., Hu S., Wu G., Zhou Q. (2017). Application of Sentinel 2 MSI images to retrieve suspended particulate matter concentrations in Poyang Lake, Remote Sensing, 9(7), 761, doi:10.3390/rs9070761.

Manh NV, Dung NV, Hung NN, Merz B, Apel H (2014) Large-scale suspended sediment transport and sedimentdeposition in the Mekong Delta. Hydrol Earth Syst Sci 18(8):3033-3053

Markert K., Schmidt C., Griffin R., Flores A., Poortinga A., Saah D., Muench R., Clinton N., Chishtie F., Kityuttachai K., Someth P., AndersonE., Aekakkararungroj A., Ganz D. (2018). Historical and operational monitoring of surface sediments in the lower Mekong basin using Landsat and Google Earth Engine cloud computing, Remote Sensing, 10, 909, doi:10.3390/rs10060909

Martimort, P. Sentinel-2: ESA's optical high-resolution mission for GMES operational services. Remote Sens. Environ. 2012, 120, 25-36.

Mekong River Commission. State of the Basin Report: 2005; Mekong River Commission: Phnom Penh, Cambodia, 2005.
Milliman, J.; Syvitski, J.P.M. Geomorphic/Tectonic Control of Sediment Discharge to the Ocean: The Importance of Small Mountainous Rivers. J. Geol. 1992, 100, 525-544, doi:10.1086/629606. [CrossRef]

Mobley C.D. (1994). Light and water: radiative tranfer in natural waters, Academic Press: San Diego, CA

Novoa, S.; Doxaran, D.; Ody, A.; Vanhellemont, Q.; Lafon, V.; Lubac, B.; Gernez, P. Atmospheric Corrections and Multi-Conditional Algorithm for Multi-Sensor Remote Sensing of Suspended Particulate Matter in Low-to-High Turbidity Levels Coastal Waters. Remote Sens. 2017, 9, 61

Nguyen T.T.H., Bui D.C., Nguyen T.P.T., Bui T.N. (2016). First experience in modelling spatial distribution of chlorophyll-a concentration and TSI in the West Lake water using Sentineal2A image, Journal of Science: Earth and Environmental Sciences, Vietnam National University, Vol. 32 , Issue $2 \mathrm{~S}, 121-130$

Novoa, S.; Doxaran, D.; Ody, A.; Vanhellemont, Q.; Lafon, V.; Lubac, B.; Gernez, P. Atmospheric Corrections and Multi-Conditional Algorithm for Multi-Sensor Remote Sensing of Suspended Particulate Matter in Low-toHighTurbidity Levels Coastal Waters. Remote Sens. 2017 ,9 , 61; doi:10.3390/rs9010061

Olet E. (2010). Water quality monitoring of Roxo reservior using LANDSAT images and In - situ measurements, International Institude for Geo-information Science and Earth Observation Enschede, the Netherlands, 69 p

Olsen DM, Dinerstein E (2002) The global 200: priority ecoregions for global conservation. Ann Mo Bot Gard 89: 199-224.

Palmer MA, Lettenmaier DP, Poff NLR, Postel SL, Richter B, et al. (2009) Climate change and river ecosystems: protection and adaptation options. Environ Manage 44: $1053-1068$.

Ritchie J.C., McHenry J.R., Schiebe F.R., Wilson R.B. (1974). The relationship of reflected solar radiantion and the concentration of sediment in the surface water of resevois, Remote Sensing of Earth Resources, Vol.3, The University of Tennessee Space Institure, Tullahoma, TN, 57 - 72.

Ritchie J.C., Cooper C.M., Jiang Y. (1987). Using Landsat multispectral scanner data to estimate suspended sediments in Moon lake, Mississippi, Remote Sensing of Environment, 23, $65-81$.

Ritchie J.C., Cooper C.M. (1988). Comparision of measured suspended semdiment concentration with suspended sediment concentrations estimated from Landsat MSS data, International Journal of Remote Sensing, 9(3), 379 - 387.

Ritchie J.C., Cooper C.M., Schiebe F.R. (1990). The relationship of MSS and TM digital data with suspended sediments, chlorophyll, and temperature in Moon lake, Mississippi, Remote Sensing of Environment, 33, 137 - 148.

Ritchie JC, Zimba PV, Everitt JH (2003) Remote Sensing Techniques to Assess Water Quality. Photogrammetric Engineering and Remote Sensing 69: 695- 704. 
Syvitski, J.P.M.; Voosmarty, C.J.; Kettner, A.J.; Green, P. Impact of Humans on the Flux of Terrestrial Sediment to the Global. Coastal Ocean. Science 2005, 308, 376-380, doi:10.1126/science.1109454.

Toming, K.; Kutser, T.; Laas, A.; Sepp, M.; Paavel, B.; Noges, T. First Experiences in Mapping Lake Water Quality Parameters with Sentinel-2 MSI Imagery. Remote Sens. 2016, 8, doi:10.3390/rs8080640.

Trinh L.H., Tarasov M.K. (2016). Evaluation of suspended sediment concentrations in surface water of the Tri An water reservoir using remote sensing, Moscow University Bulletin. Series 5. Geography, Vol.2, 38-44

U.S. Environmental Protection Agency (EPA) (2000) National water quality inventory, report to congress. Washington DC, USA.

Venterink HO, Vermaat JJE, Olde Venterink H, Vermaat JJE, Pronk M, Wiegman F, Verhoeven JTA (2006). Importance of sediment deposition and denitrification for nutrient retention in floodplain wetlands. Appl Veg. Sci 9 (2):163-174

Vermote, E.F.; Tanré, D.; Deuze, J.L.; Herman, M.; Morcette, J.-J. Second simulation of the satellite signal in the solar spectrum, 6S: An overview. IEEE Trans. Geosci. Remote Sens. 1997, 35, 675-686.

Xue Z, Liu JP, Ge Q (2011) Changes in hydrology and sediment delivery of the Mekong River in the last 50 years: connection to damming, monsoon, and ENSO. Earth Surface Process and Landforms 36: 296-308.

Wang J., Tian Q. (2013). Estimation of total susended solids concentration by hyperspectral remote sensing in Liaodong bay, Indian Journal of Geo-Marine Science, Vol. 44(8), 1137 -1144 .

Wang J.J., Lu X.X., Liew S.C., Zhou Y. (2009). Retrieval of suspended sediment concentrations in large turbid rivers using Landsat ETM+: an example from the Yangtze River, China, Earth Surface Processes and Landforms, 34, 1082 1092.

Wang X.J., Ma T. (2001). Application of remote sensing techniques in monitoring and assessing the water quality of Taihu Lake, Bulletin of Environmental Contamination and Toxicology, 67(2), $863-870$.

Wang, M.; Shi, W. Cloud masking for ocean color data processing in the coastal regions. IEEE Trans. Geosci. Remote Sens. 2006, 44, 3196-3205. [CrossRef]

Wackerman C., Hayden A., Jonik J. (2017). Deriving spatial and temporal context for point measurements of suspended sediment concentration using remote sensing imagery in the Mekong Delta, Continental Shelf Research, Vol.147, 231 245.

Yang W, Matsushita B, Chen J, Fukushima T (2011) Estimating constituent concentrations in case II waters from MERIS satellite data by semi-analytical model optimizing and look-up tables. Remote Sensing Environ 115: $1247-1259$.
Yepez S., Laraque A., De Sa J., Carrera J., Castenllanos B., Gallay M., Lopez J. (2018). Retrieval of suspended sediment concentrations using Landsat 8 OLI satellite images in the Orinoco River (Venezuela), Comptes Rendus Geoscience, Vol.350, Issues 1-2, $20-30$.

Zhou W., Wang S., Zhou Y., Troy A. (2006). Mapping the concentrations of total suspended matter in Lake Taihu, China using Landsat 5 TM data, International Journal of Remote Sensing, 27(6), 1177 - 1191. 